\title{
O CONCEITO DE ÁREA RURAL CONSOLIDADA NO CÓDIGO FLORESTAL DE
} 2012: PRINCIPAIS CONTROVÉRSIAS

\author{
Daíse de Felippe* \\ Flávia Trentini**
}

\section{Resumo}

O artigo tem como objeto a análise do instituto da área rural consolidada, instituída pelo Código Florestal de 2012. Por meio da pesquisa bibliográfica e documental, pretende analisar o conceito e o marco temporal de 22/07/2008, a partir da doutrina e jurisprudência do STF, e verificar sua compatibilidade com preceitos de proteção ao meio ambiente da ordem constitucional. Concluiu-se que apesar do posicionamento da doutrina ser pela inconstitucionalidade dos dispositivos questionados nas ADI's, o contexto fático e político da situação dos imóveis rurais contribuiu para aprovação no Congresso Nacional, posicionamento que foi ratificado pelo STF em 28/02/ 2018.

Palavras-chave: Áreas consolidadas. Imóvel rural. Código Florestal. Lei n. 12.651/2012. Regularização ambiental.

\section{THE CONCEPT OF CONSOLIDATED RURAL AREA IN THE BRAZILIAN FORESTRY CODE OF 2012: CONTROVERSIAL ISSUES}

\begin{abstract}
The article aims to analyze the institute of the consolidated rural area, setted by the Forestry Code of 2012. Through the bibliographical and documentary research, it intends to analyze the concept and temporal frame of July 22, 2008, based on the doctrine and jurisprudence of STF, and verify its compatibility with precepts of environmental protection. It concluded that, despite the positioning of the doctrine for the unconstitutionality of the devices in the ADI's, the phatic and political context of the rural properties contributed to its approval in the National Congress, what was ratified by STF on February 28, 2018.
\end{abstract}

Keywords: Consolidated areas. Rural property. Forestry Code. Law no. 12.651/2012. Environmental regularization.

\footnotetext{
* Mestranda do Programa de Pós Graduação em Direito da Faculdade de Direito de Ribeirão Preto. Avenida Bandeirantes, 3900 - Monte Alegre - Ribeirão Preto - SP - CEP: 14040-906, Campus USP - R. Prof. Aymar Baptista Prado, 835. <daise.felippe@usp.br>.

** Professora Livre Docente da Faculdade de Direito de Ribeirão Preto. Avenida Bandeirantes, 3900 - Monte Alegre - Ribeirão Preto - SP - CEP: 14040-906, Campus USP - R. Prof. Aymar Baptista Prado, 835. $<$ trentini@usp.br>.
} 


\section{INTRODUÇÃO}

A promulgação do mais recente Código Florestal brasileiro inaugurou no ordenamento jurídico o conceito de área rural consolidada, caracterizada como sendo a "área de imóvel rural com ocupação antrópica preexistente a 22 de julho de 2008, com edificações, benfeitorias ou atividades agrossilvipastoris, admitida, neste último caso, a adoção do regime de pousio" (BRASIL, 2012a, art. $3^{\circ}$, IV).

Assim, num contexto de fomentado debate político em torno da aprovação da lei pelo Congresso Nacional, optou o legislador por considerar como consolidadas as áreas do imóvel rural que já haviam sido convertidas, grosso modo, para uso humano da terra na data de 22 de julho de 2008. ${ }^{1}$

Á época do trâmite legislativo do Código, bem como nos anos que o antecederam, houve forte pressão política por parte da bancada ruralista do Congresso pela reforma da legislação ambiental. Alegaram, entre outros pontos, que da maneira como se encontrava, grande parte dos imóveis rurais estaria em desacordo com o Código Florestal de 1965 (BRASIL, 1965). Por isso, a reforma fazia-se necessária para contribuir com a regularização ambiental dessas propriedades.

Entretanto, ainda no âmbito de tramitação da lei que o instituiu, bem como no posicionamento doutrinário que vem se firmando nestes cinco anos de vigência do Código, pode-se verificar a existência de diversas controvérsias a respeito das áreas rurais consolidadas, com destaque para a adoção do marco temporal de 22 de julho de 2008.

Sustentou-se, conforme se observa do texto das Ações Diretas de Inconstitucionalidade (ADI's) que tramitaram perante o Supremo Tribunal Federal (STF), que diversos artigos do Código Florestal que trazem a data mencionada seriam inconstitucionais ${ }^{2}$, por não respeitarem o princípio da reparação dos danos ambientais, o da restauração dos processos ecológicos essenciais, e a exigência de que a propriedade rural atenda a sua função social. $^{3}$

Ante a relevância e atualidade do tema, pretende-se analisar a questão a partir da pesquisa à doutrina ambiental, bem como a outros documentos pertinentes relacionados ao trâmite do Código Florestal e às ADI's que tramitaram no Supremo Tribunal Federal (STF)

\footnotetext{
${ }^{1}$ Referida data será objeto de análise detalhada no item " 4.2 ” do presente trabalho.

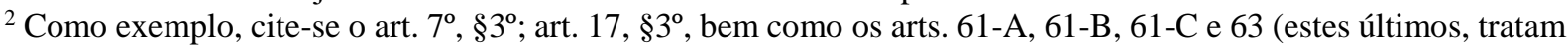
das áreas consolidadas em APP's), todos da lei n. 12.651/2012 e com redação dada pela lei n. 12.727/2012.

${ }^{3}$ Tais são os preceitos dos seguintes dispositivos da Constituição de 1988: art. 186; art. 225, $\$ 1^{\circ}$, inciso I e III; e $\S 3^{\circ}$.
} 
impugnando referida lei. Assim, o objetivo geral do presente trabalho corresponde a analisar o conceito de área rural consolidada, bem como seu marco temporal, sobretudo no que tange a sua constitucionalidade, verificando os posicionamentos doutrinário e jurisprudencial ${ }^{4}$ atuais.

Para isso, o texto que se segue se organiza da seguinte maneira: no tópico "2", será abordada a inserção da tutela ambiental no Brasil, com destaque para os dispositivos inseridos com a Constituição da República de 1988; no item “3”, faz-se um panorama do surgimento do conceito de área rural consolidada no Brasil, a partir da promulgação do Código Florestal de 2012; no item “4”, será tratado o conceito de área rural consolidada pela lei que instituiu o Código de 2012 e em seguida as considerações a respeito do marco temporal de 22 de julho de 2008; por fim, no item "5" será discutido o tema deste artigo com base no recente julgamento pelo STF das ADI's propostas em impugnação ao Código Florestal, além desta introdução e de um último tópico com as conclusões do trabalho.

\section{A INSERÇÃO DA PROTEÇÃO AMBIENTAL NO BRASIL E NA CONSTITUIÇÃO DE 1988}

A realização da Conferência de Estocolmo em 1972, organizada pela Organização das Nações Unidas (ONU) para discutir a questão da degradação ambiental pelos chefes de Estado de diversos países, repercutiu de forma global. No Brasil, foi instituída a Política Nacional do Meio Ambiente, por meio da promulgação da lei n. 6.938 de 31 de agosto de 1981 (BRASIL, 1981).

Foram dados, com a nova legislação, os primeiros passos no sentido de estabelecer Políticas Públicas para a preservação do meio ambiente no Brasil. Pela primeira vez foram trazidos os conceitos de meio ambiente, poluição, poluidor, recursos ambientais, entre outros (LEUZINGER; CUREAU, 2008).

Importante mencionar também a criação, com a referida lei, dos instrumentos da Política Nacional do Meio Ambiente, por meio dos quais se estabeleceram formas de comando, controle, fiscalização, aplicação de sanções e imposição de custos para a tutela ambiental. Foi criado, também, o Sistema Nacional de Meio Ambiente (SISNAMA), que, por meio dos órgãos

\footnotetext{
${ }^{4}$ Importante mencionar que no último dia 28 de fevereiro, o plenário do STF terminou de julgar todas as ações que tramitavam em impugnação ao Código Florestal. Confira em: <https://g1.globo.com/politica/noticia/stfdecide-manter-anistia-do-codigo-florestal.ghtml>. As questões serão analisadas principalmente com base no voto do ministro Celso de Mello, o último a votar, por ser o único disponibilizado virtualmente até o momento.
} 
que o compõe na esfera federal, estadual e municipal, tem o objetivo de elaborar e executar as políticas que visam à proteção do ambiente natural.

No entanto, foi tão-somente com a promulgação da Constituição da República de 1988 que foi consagrado o meio ambiente como bem jurídico a ser tutelado, abordando-o como direito difuso de todos e, ao mesmo tempo, objeto do dever da coletividade de defendê-lo e preservá-lo (FIORILLO, 2010).

Desse modo, a Carta Maior do Brasil trata, pela primeira vez, do direito ao meio ambiente ecologicamente equilibrado, reconhecido esse pela doutrina como um dos princípios gerais do Direito Ambiental. ${ }^{5}$

Como explica Paulo Affonso Leme Machado (2010, p. 59):

O direito ao meio ambiente equilibrado, do ponto de vista ecológico, consubstancia-se na conservação das propriedades e das funções naturais desse meio, de forma a permitir a 'existência, a evolução e o desenvolvimento dos seres vivos'.

Infere-se da parte final do mencionado artigo, ainda, o princípio ambiental do desenvolvimento sustentável, pelo estabelecimento do dever do Poder Público e da coletividade em defender e preservar o meio ambiente para as presentes e futuras gerações (FIORILLO, 2010).

Isto porque os recursos naturais não são inesgotáveis (FIORILLO, 2010, p. 78). Assim, para resguardá-los para as próximas gerações, é necessário que as atividades humanas econômicas sejam executadas de forma que não findem com esses recursos que se encontram à disposição na natureza. Nas palavras de Celso Antônio Pacheco Fiorillo (2010, p. 86):

Como se percebe, o princípio possui grande importância, porquanto numa sociedade desregrada, à deriva de parâmetros de livre concorrência e iniciativa, o caminho inexorável para o caos ambiental é uma certeza. Não há dúvida de que o desenvolvimento econômico também é um valor precioso da sociedade. Todavia, a preservação ambiental e o desenvolvimento econômico devem coexistir, de modo que aquela não acarrete a anulação deste.

Neste sentido, ao tratar da ordem econômica brasileira, a Constituição de 88 afirma que esta deverá reger-se pelos ditames da justiça social. Estabelece a defesa do meio ambiente

\footnotetext{
${ }^{5}$ Art. 225. Todos têm direito ao meio ambiente ecologicamente equilibrado, bem de uso comum do povo e essencial à sadia qualidade de vida, impondo-se ao Poder Público e à coletividade o dever de defendê-lo e preserválo para as presentes e futuras gerações (BRASIL, 1988).
} 
como um dos princípios a ser seguido pelo Estado, nos termos do artigo 170, inciso $\mathrm{VI}^{6}$ da Carta.

Desta forma, deve haver uma harmonização entre os diversos direitos envolvidos no Estado como sociedade politicamente organizada (LEHFELD; CARVALHO, 2013). Considerados em suas dimensões sociais e econômicas, possibilita-se a sua coexistência com a tutela ambiental, para que essa não seja prejudicada em face do desenvolvimento econômico da sociedade contemporânea.

Os autores sugerem o surgimento na atualidade do Estado Socioambiental de Direito, tendo em vista a dimensão ecológica incorporada ao Estado Democrático de Direito. A sustentabilidade, portanto, qualifica e caracteriza o desenvolvimento desse Estado (LEHFELD; CARVALHO, 2013).

Igualmente importante ressaltar a previsão constante da Constituição de 88 , no Capítulo que regula a Política Agrícola e Fundiária brasileira, que estabelece a utilização adequada dos recursos naturais disponíveis e a preservação do meio ambiente como requisitos para o cumprimento da função social da propriedade rural. ${ }^{7}$

Além disso, o texto constitucional consagrou, no $\S 3^{\circ}$ do já mencionado artigo 225 , o dever de reparação do dano causado ao ambiente, pelo infrator, seja este pessoa física ou jurídica, nos seguintes termos:

$\S 3^{\circ}$ As condutas e atividades consideradas lesivas ao meio ambiente sujeitarão os infratores, pessoas físicas ou jurídicas, a sanções penais e administrativas, independentemente da obrigação de reparar os danos causados (BRASIL, 1988).

Assim, segundo o que dispõe esse dispositivo, pode-se dizer que é possível a responsabilização do infrator ambiental nas esferas administrativa, penal e civil. Por ser a que convém com o escopo do presente trabalho, a responsabilidade ambiental administrativa será abordada nos próximos parágrafos.

\footnotetext{
${ }^{6}$ Art. 170. A ordem econômica, fundada na valorização do trabalho humano e na livre iniciativa, tem por fim assegurar a todos existência digna, conforme os ditames da justiça social, observados os seguintes princípios:

(...) VI - defesa do meio ambiente, inclusive mediante tratamento diferenciado conforme o impacto ambiental dos produtos e serviços e de seus processos de elaboração e prestação; (BRASIL, 1988).

7 Art. 186. A função social é cumprida quando a propriedade rural atende, simultaneamente, segundo critérios e graus de exigência estabelecidos em lei, aos seguintes requisitos: (...) II - utilização adequada dos recursos naturais disponíveis e preservação do meio ambiente; (BRASIL, 1988).
} 
A lei n. 9.605 trouxe no artigo 70 a definição de infração administrativa ambiental como "toda ação ou omissão que viole as regras jurídicas de uso, gozo, promoção, proteção e recuperação do meio ambiente". Os dois dispositivos seguintes da lei tratam do processo administrativo para apuração da infração ambiental e das sanções administrativas, as quais podem ser citadas, a advertência, a multa simples, a multa diária, apreensão de animais, produtos, subprodutos, instrumentos, petrechos e outros utilizados na infração (BRASIL, 1998).

O Decreto n. 3.179, de 21 de setembro de 1999 (BRASIL, 1999), por sua vez, foi o responsável por regulamentar a lei mencionada, especificando as infrações administrativas ao ambiente, o qual foi revogado pelo Decreto n. 6.514, de 22 de julho de 2008, atualmente em vigor $^{8}$.

Norma Sueli Padilha destaca também a importância do sistema de responsabilidades ambientais (administrativa, penal e civil), por seu caráter repressivo e reparador do dano ambiental, indispensável na atual sociedade de risco. Segundo a autora, o ideal seria a possibilidade de aplicação em todos os casos dos princípios da precaução, da prevenção e do poluidor-pagador (em seu aspecto preventivo), evitando-se a ocorrência do dano ambiental, “[...] que é altamente prejudicial à qualidade do meio ambiente” (2010, p. 279).

Padilha destaca ainda o que dispõe o $\$ 1^{\circ}$, inciso I do artigo 225 da Constituição, segundo o qual incumbe ao poder Público "[...] preservar e restaurar os processos ecológicos essenciais e prover o manejo ecológico das espécies e ecossistemas;” (BRASIL, 1988), pois conforme seu entendimento, neste dispositivo adota-se, no mesmo sentido, o princípio da responsabilização. (PADILHA, 2010, p. 277).

\section{O SURGIMENTO dO CONCEITO DE ÁREA RURAL CONSOLIDADA NO CÓDIGO FLORESTAL}

As polêmicas discussões ao longo do trâmite legislativo da lei n. 12.651 no Congresso Nacional, que instituiu o Código Florestal atual, despertou forte atuação dos grupos de interesse na reforma da legislação ambiental. Segundo a equipe da Organização "Terra de Direitos" (PRIOSTE; AVANCI; PACHER; VIEIRA, 2009) de maneira geral, eram dois os grupos de interesse na reforma da legislação ambiental.

O primeiro, representando o interesse dos grandes proprietários de terra, pregava pela aplicação de uma orientação liberal na agricultura, ou seja, da ausência ou mínima intervenção

\footnotetext{
${ }^{8} \mathrm{O}$ Decreto dispõe sobre as infrações e sanções administrativas ao meio ambiente, estabelece o processo administrativo federal para apuração destas infrações e dá outras providências. (BRASIL, 2008).
} 
estatal no setor e defendia a plena utilização da terra pelo proprietário. A bancada ruralista e a Confederação da Agricultura e Pecuária do Brasil (CNA) podem ser enquadradas nesse grupo.

O segundo pregava pela proteção da função socioambiental da propriedade rural, assegurando a preservação da vegetação nativa como bem jurídico ambiental. Nesse grupo destaca-se a presença das Organizações Não-Governamentais (ONGs) Ambientalistas, do Ministério Público, o qual tem a função de fazer observar o cumprimento da lei e a defesa dos direitos coletivos difusos; e do Conselho Nacional do Meio Ambiente (CONAMA).

Nesse contexto se inseriu a discussão a respeito do tratamento jurídico a ser dado às áreas que já haviam sido desmatadas para o uso da terra, o que viria a originar as chamadas áreas rurais consolidadas. Isto porque um dos principais argumentos levantados pela bancada ruralista, e em torno do qual se gerou enorme polêmica no âmbito do trâmite legislativo do Código de 2012, foi o da inviabilidade econômica dos pequenos e médios produtores rurais (PETERS; PANASOLO, 2014, p. 25). Argumentava-se que enfrentavam dificuldades para a produção de acordo com as regras ambientais.

Neste sentido foram os argumentos apresentados na Cartilha elaborada pela CNA após a aprovação na Câmara, intitulada "Produzir e preservar - Por que precisamos de um novo Código Florestal?” (CNA, 2011). Nela, a consolidação das áreas abertas até julho de $2008^{9}$ é apresentada como avanço, pois não se trataria de uma anistia aos desmatadores (referindo-se ao argumento apresentado pelos ambientalistas), mas sim a substituição de multas administrativas por obrigações de regularização da propriedade rural $^{10}$.

Por isso, o novo texto da lei apresentado estaria dando prioridade à preservação ambiental em detrimento à arrecadação de recursos financeiros pelo Estado, na forma de multas. Esta medida, segundo o que consta na Cartilha, poderia tirar da ilegalidade 90\% (noventa por cento) dos estabelecimentos rurais.

Por outro lado, a Cartilha "Código Florestal - Entenda o que está em jogo com a reforma da nossa legislação ambiental" (SOS FLORESTAS, 2011), elaborada pela ONG SOS Florestas com apoio da WWF, se refere à questão da definição pelo texto da lei das áreas rurais consolidadas com implicação, de fato, em anistia aos crimes ambientais, ante o fim da obrigação

\footnotetext{
9 As áreas rurais consolidadas, conforme ficaram assim definidas pelo Código de 2012, bem como a data mencionada, serão objeto de explicação detalhada no tópico "4" adiante.

${ }^{10}$ A cartilha se refere, neste ponto, à instituição do Programa de Regularização Ambiental (PRA), por meio do qual as multas por infração ambiental aplicadas até 22/07/2008 ficarão suspensas após a assinatura do termo de adesão e compromisso de regularização ambiental pelo proprietário ou posseiro rural, nos termos do artigo 59 e ss. do Código Florestal.
} 
de se recuperar áreas desmatadas ilegalmente até 22/07/2008, no que se incluem topos de morros, margens de rios, restingas, manguezais, nascentes, montanhas e terrenos íngremes ${ }^{11}$.

Segundo a Cartilha, tais medidas têm consequências danosas ao meio ambiente, como o estímulo a novas ilegalidades e o reforço da sensação de impunidade; os crimes ambientais que, cometidos ao longo de 43 anos, serão ignorados e perdoados, além de abrir espaço para que mais ocupações em áreas de risco ocorram, como em encostas e dunas (SOS FLORESTAS, 2011, p. 13).

Após aprovado o Código Florestal de 2012, vários dispositivos foram objeto de discussão nas Ações Diretas de Inconstitucionalidade (ADI's) n. 4901, 4902, 4903 e 4937 (BRASIL, 2012c), que tramitaram perante o Supremo Tribunal Federal, sob relatoria do ministro Luiz Fux, e que foram julgadas parcialmente procedentes em 28/02/2018 (BRASIL, 2018). O conceito de área rural consolidada inaugurado pelo Código, e o marco temporal de 22 de julho de 2008 são abordados nas ações em diversos pontos, e por tal razão se torna importante sua análise. ${ }^{12}$

\section{AS ÁREAS RURAIS CONSOLIDADAS NO CÓDIGO FLORESTAL ATUAL}

\subsection{Conceito e aspectos principais}

O Código Florestal brasileiro, sancionado em 2012, inovou ao trazer o conceito de área rural consolidada, sendo assim caracterizado pelo texto da lei:

Art. $3^{\circ}$, IV - área rural consolidada: área de imóvel rural com ocupação antrópica preexistente a 22 de julho de 2008, com edificações, benfeitorias ou atividades agrossilvipastoris, admitida, neste último caso, a adoção do regime de pousio; (BRASIL, 2012) ${ }^{13}$

A definição é importante porque representa a intenção do legislador em dar tratamento jurídico diferenciado para as áreas rurais em que já havia ocorrido, à data mencionada,

\footnotetext{
${ }^{11}$ Todos os ambientes descritos se enquadram, nos termos dos incisos do art. $4^{\circ}$ do Código Florestal, em Áreas de Preservação Permanente.

${ }^{12} \mathrm{O}$ tópico " 5 " do trabalho, irá apresentar de forma mais detalhada o resultado do julgamento, especialmente no que envolve o conceito e ao marco temporal das áreas rurais consolidadas.

${ }^{13} \mathrm{O}$ mesmo artigo, no inciso XXIV, assim caracteriza o pousio: prática de interrupção temporária de atividades ou usos agrícolas, pecuários ou silviculturais, por no máximo 5 (cinco) anos, para possibilitar a recuperação da capacidade de uso ou da estrutura física do solo. (BRASIL, 2012).
} 
conversão das florestas e outras formas de vegetação para uso alternativo do $\operatorname{solo}^{14}$, considerando-se tais áreas como aquelas as quais o ser humano já tenha ocupado com a finalidade de praticar atividade do meio rural.

Segundo Leonardo Papp, pode-se entender por “ocupação antrópica” a conversão para uso alternativo do solo, ou seja, como o próprio Código conceitua, como "a substituição de vegetação nativa e formações sucessoras para outras coberturas do solo" (PAPP, 2012, p, 128).

Para a caracterização da área rural consolidada, assim, é suficiente a existência efetiva ou potencial de atividades agrossilvipastoris, sendo este o gênero nas quais se enquadram as espécies agricultura, pecuária e silvicultura. Por decorrência lógica, as áreas rurais consolidadas abarcam também as edificações e benfeitorias relacionadas, como estradas internas, galpões, estufas, residências e sistemas de irrigação. (PAPP, 2012, p, 127).

Em relação à existência em potencial de uso das áreas rurais consolidadas, a legislação abarca inclusive as áreas que possam ter sido convertidas para realização futura das atividades agrossilvipastoris, não necessitando, portanto, que já tenham sido efetivadas à data de 22/07/2008.

Em relação ao termo "preexistente", por sua vez, um estudo comparativo realizado pela Consultoria Legislativa da Câmara dos Deputados acerca da lei n. 12.651/2012, da MP $571 / 2012$ e do texto aprovado no Senado, afirma que "O uso do termo preexistente flexibiliza demasiadamente o conceito. Qualquer ocupação antrópica preexistente passa potencialmente a ser considerada 'consolidada"” (BRASIL, 2012, p. 6).

O mesmo estudo ressalta, também, “[...] que culturas temporárias não geram irreversibilidade de ocupação.", alertando para o fato de que a regularização dessas áreas de forma ampla como concedida pelo Código, abre a possibilidade de que situações em imóveis rurais que antes da promulgação da lei eram passivos ambientais, não sejam mais objeto de recuperação ambiental (BRASIL, 2012, p. 15).

Isto porque o conceito de área rural consolidada e o seu marco temporal, repercutem em uma série de questões na sistemática dos dispositivos da lei. A doutrina aponta o papel da

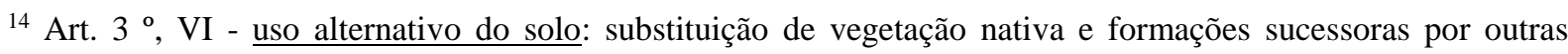
coberturas do solo, como atividades agropecuárias, industriais, de geração e transmissão de energia, de mineração e de transporte, assentamentos urbanos ou outras formas de ocupação humana; (BRASIL, 2012).
} 
inovação trazida pelo Código em permitir a ocupação humana nas Áreas de Preservação Permanente (APP's) e Áreas de Reserva Legal (ARL) (BRANDÃO, 2012, p. 69). ${ }^{15}$

De fato, o Código Florestal prevê o regime das áreas rurais consolidadas em capítulo próprio, tratando especificamente daquelas em APP's e em ARL, separadamente. ${ }^{16}$ Além disso, o tratamento dado às APP's se diferencia em relação às APP's em áreas não consolidadas, que são tratadas nas Disposições Permanentes, do artigo $4^{\mathrm{a}}$ ao $9^{\circ}$ do Código; daquele dado às APP's em áreas consolidadas, regidas pelas Disposições Transitórias, mais especificamente do artigo 61-A ao 64 da lei.

\subsection{O marco temporal de 22 de julho de 2008}

O aspecto temporal das áreas rurais consolidadas foi propositadamente reservado para este tópico separado, por merecer observações detalhadas. Primeiramente, cumpre explicar o motivo da adoção pelo legislador do marco de 22 de julho de 2008 , tanto no artigo $3^{\circ}$, inciso IV, que caracteriza tais áreas, como ao longo de toda a lei.

A referida data é a da promulgação no ordenamento jurídico do Decreto n. 6.514, que “dispõe sobre as infrações e sanções administrativas ao meio ambiente e estabelece o processo administrativo federal para apuração destas infrações" (BRASIL, 2008). Isto significa que esse marco temporal foi adotado partindo-se da ideia de que antes dele não havia previsão legal de infrações administrativas ambientais. Assim, seriam considerados ilícitos tão-somente os atos praticados contra o ambiente a partir da mencionada data (MILARÉ; MACHADO, 2012). ${ }^{17}$

No entanto, explica a doutrina ambiental que a adoção do marco de 22 de julho de 2008 concede anistia aos infratores ambientais, pois permite que aqueles que praticaram ilícitos em momento anterior ao Decreto possam regularizar sua situação. Afirmam que foi desconsiderada a legislação anteriormente em vigor, a saber, o Decreto n. 3179/1999 (BRASIL, 1999), que já previa infrações contra a flora e sanções para exploração em área de Reserva Legal (MILARÉ; MACHADO, 2012).

\footnotetext{
${ }^{15}$ Encontra-se na nota de rodapé n. 172. Confira também texto da petição inicial da ADIN 4901, disponível em: http://terradedireitos.org.br/noticias/noticias/inconstitucionalidades-do-novo-codigo-florestal-serao-discutidasem-audiencia-publica-no-stf/20406, p. 32 da parte II (comentário ao art. $3^{\circ}$, inciso IV).

${ }^{16}$ O Capítulo XII do Código, após tratar das Disposições gerais na Seção I, na qual dispõe sobre o Programa de Regularização Ambiental, na Seção II regulamenta as Áreas Consolidadas em Áreas de Preservação Permanente; e, na sequência, na Seção III, regulamenta as Áreas Consolidadas em Áreas de Reserva Legal. (BRASIL, 2012).
} 
De fato, em matéria de regulamentação da Lei de Crimes Ambientais (BRASIL, 1998), o Decreto n. 6.514/2008 revogou o Decreto n. 3.179/1999, mas este já previa as infrações e respectivas sanções para os crimes ambientais cometidos em áreas denominadas de "preservação permanente" e de "reserva legal”, nos termos da própria redação do Decreto. ${ }^{18}$ Por esta razão, não haveria qualquer justificativa plausível para a adoção da data do Decreto mais recente (de 2008) como marco temporal, o que ocorreu sem qualquer respaldo técnicojurídico (NOBRE, 2014; BRASIL, 2012b).

Por isso, a adoção da data de 22 de julho de 2008 no conceito de área rural consolidada teria tido como objetivo isentar os causadores de danos ambientais da obrigação de reparação. A medida seria inconstitucional, por ferir os princípios consagrados no artigo 225 da Constituição, especialmente o princípio da reparação dos danos ambientais, o da restauração dos processos ecológicos essenciais, e abriria margem para uma anistia coletiva dos ilícitos ambientais, por aplicação analógica a todo e qualquer dano ambiental, mesmo que posterior ao marco (NOBRE, 2014).

Neste ponto cumpre pontuar que os requisitos para comprovação da área rural consolidada são muito tênues, “como anotações de 'fatos históricos', registros de comercialização, dados agropecuários, etc.” (BRASIL, 2012b, p. 6), o que de fato pode abrir margem para que causadores de danos ambientais ocorridos após 2008 possam se beneficiar dos dispositivos do Código que utilizam a data como marco.

Por outro lado, há também o entendimento de que a adoção da data de 22 de julho de 2008 feriria o próprio princípio da igualdade, por propiciar tratamento desigual a proprietários rurais que igualmente desmataram áreas ambientalmente protegidas (BRASIL, 1988, art. 5, caput). Tal é o posicionamento explicitado na redação da petição inicial da ADI 4937 (BRASIL, 2012c; BRASIL, 2012b), de autoria do Partido Socialismo e Liberdade (PSOL), em questionamento ao parágrafo $3^{\circ}$ de artigo $7^{\circ}$ do Código Florestal, que isenta de recuperação a supressão de vegetação em APP's que tenha ocorrido antes de 22 de julho de 2008.

De maneira geral, pode-se dizer que a adoção do marco de 22 de julho de 2008 para caracterização das áreas rurais consolidadas, bem como sua utilização em diversos outros dispositivos ao longo da legislação florestal de 2012, é controversa. Por essa razão a data mencionada foi impugnada pelas ações que questionaram a constitucionalidade de vários dispositivos do Código Florestal, e que serão objeto de análise a seguir.

\footnotetext{
${ }^{18}$ Destaca-se, como exemplo, os artigos 25 e 38 do Decreto n. 3179/1999.
} 


\section{BREVE ANÁLISE DO JULGAMENTO DAS ADIS PELO STF}

Apesar de o dispositivo que trata do conceito de área rural consolidada (artigo $3^{\circ}$, inciso IV) não ter sido objeto de discussão nas ADI's ${ }^{19}$ propostas em impugnação ao Código Florestal, diversos dispositivos que abarcam seu conceito indiretamente ou que estabelecem, igualmente, o marco temporal de 22/07/2008 para permitir determinadas condutas em detrimento do ambiente, estão sendo questionados naqueles processos, a exemplo do artigo $7^{\circ}$, parágrafo $3^{\circ}$ e do artigo 17 , parágrafo $3^{\circ}$, ambos que utilizam a data referida para consolidar as áreas em que ocorreram supressão de vegetação anterior àquele momento em APP's e ARL, respectivamente.

Ademais, quase todos os dispositivos que tratam das Áreas Consolidadas em APP's, ou seja, a matéria regida pelo artigo 61-A ao 63, estão sendo também impugnados pela ADI 4902, por entender que violam gravemente dispositivos de ordem constitucional de proteção ambiental.

Até a data da finalização do presente trabalho, o acórdão do julgamento em conjunto pelo plenário STF de todas as ADI's propostas em face dos dispositivos do Código de 2012 ainda não se encontrava disponível para consulta ao público. ${ }^{20}$ Entre os votos dos ministros, apenas o do ministro Celso de Mello estava disponível na íntegra, o qual foi utilizado para análise do posicionamento adotado pelo Supremo em relação ao tema discutido neste trabalho.

Nesse sentido, observa-se que o ministro, que foi o último a votar e assim acabou por decidir o julgamento final em diversos pontos, votou pela total improcedência da ADI 4902, de forma que os dispositivos que utilizam o marco temporal para consolidar as áreas em que ocorreram supressão de vegetação anterior a 22/07/2008 em APP's e ARL foram considerados constitucionais. $^{21}$

Além disso, destaca-se outro dispositivo importante que traz o marco temporal discutido e que foi considerado constitucional por 6 (seis) votos a 5 (cinco) no plenário do Supremo: a possibilidade de anistia aos crimes ambientais cometidos até 22/07/2008, quando o proprietário do imóvel aderisse ao Programa de Regularização Ambiental (PRA). (D’AGOSTINO, 2018).

\footnotetext{
${ }^{19}$ ADI's no 4901, 4902, 4903 e 4937.

${ }^{20}$ Conforme se verifica em: <http://portal.stf.jus.br/processos/detalhe.asp?incidente=4355097> .

${ }^{21}$ Artigo $7^{\circ}$, parágrafo $3^{\circ}$ e artigo 17 , parágrafo $3^{\circ}$ (BRASIL, 2012a).
} 
Conforme ponderou o ministro Celso de Mello, além de ser possível no ordenamento jurídico brasileiro a concessão de anistia não só a crimes políticos, mas também comuns, a norma como prevista nos termos do artigo $60^{22}$ do Código poderia "induzir os agentes que tenham praticado determinados delitos ambientais antes de 22/07/2008 a solver o seu passivo ambiental” (BRASIL, 2018, p. 34).

Além disso, a norma em questão não seria arbitrária nem estaria comprometendo o núcleo essencial que qualifica o regime constitucional de proteção ambiental. Importante considerar, como ponderado pelo ministro Celso de Mello, que o proprietário de imóvel que se encontra em situação de irregularidade perante a legislação ambiental só terá a extinção definitiva da punibilidade pelo crime ambiental se efetivamente adimplidas, regular e integralmente, as obrigações estabelecidas no termo de compromisso assinado junto ao órgão ambiental competente pelo PRA (BRASIL, 2018)

\section{CONCLUSÕES}

Conforme apontado ao longo do trabalho, especialmente no item "3", que tratou dos argumentos levantados durante a discussão do trâmite legislativo do Código Florestal de 2012, a justificativa apresentada para a criação do conceito de área rural consolidada, bem como para muitos outros dispositivos da lei que adotaram o marco temporal de 2008 para isentar proprietários de responsabilizações por dano ambiental, seria a de que "Áreas que foram ocupadas 'historicamente', às vezes com 'ajuda do governo', ou quando 'era permitido', não precisam ser recuperadas, pois significaria perda para a agricultura nacional e injustiça para muitos agricultores." (SOS FLORESTAS, 2011, p. 13).

Nesse sentido se posicionou o grupo político interessado na aprovação das referidas inovações, incluindo a inserção do conceito de área rural consolidada no Código de 2012. Afirmavam que $90 \%$ dos estabelecimentos rurais, com as medidas, sairiam da ilegalidade. Além disso, que não se tratava de anistia, pois os proprietários e posseiros rurais estariam vinculados às obrigações de regularização a partir do estabelecimento do PRA pelos entes da Federação.

\footnotetext{
${ }^{22}$ Art. 60. A assinatura de termo de compromisso para regularização de imóvel ou posse rural perante o órgão ambiental competente, mencionado no art. 59, suspenderá a punibilidade dos crimes previstos nos arts. 38, 39 e48 da Lei $\mathrm{n}^{\circ}$ 9.605, de 12 de fevereiro de 1998, enquanto o termo estiver sendo cumprido

$\S 1^{\circ}$ A prescrição ficará interrompida durante o período de suspensão da pretensão punitiva.

$\S 2^{2}$ Extingue-se a punibilidade com a efetiva regularização prevista nesta Lei (BRASIL, 2012a).
} 
Do ponto de vista estritamente jurídico, com esteio na Constituição de 1988, especialmente pelos princípios ambientais consagrados pelo artigo 225 , em específico no parágrafo $1^{\circ}$, incisos I e III e parágrafo $3^{\circ}$ - o da restauração dos processos ecológicos essenciais, a proteção dos espaços territoriais especialmente protegidos, o princípio da reparação dos danos ambientais; na exigência de que toda propriedade cumpra sua função social (art. 186); e na teoria da responsabilidade pelo dano ambiental, de fato, a constitucionalidade de diversos dispositivos do Código Florestal mais recente poderia ser questionada.

Entretanto, o evidente interesse político dos proprietários rurais em relação às alterações da legislação ambiental que lhes seriam benéficas, incluindo o advento do conceito de área rural consolidada e demais implicações do termo ao longo de toda a lei, teve força o suficiente para que o Código fosse assim aprovado. O que se observa, assim, é que os critérios políticos ultrapassaram, na prática, os fundamentos técnico-jurídicos que pudessem prevalecer.

Não se pode esquecer que a maioria esmagadora das propriedades rurais se encontrava em desacordo com a legislação ambiental, sendo este um forte argumento utilizado pela bancada ruralista. Nesse sentido, no entendimento do consultor do Senado Federal em momento da iminência das discussões sobre a reforma do Código, Gustavo Taglialegna, "o tratamento a ser dado às produções agrícolas consolidadas dentro das áreas de preservação permanente é uma questão política, que deve ser democraticamente discutida pelo Congresso Nacional.” (BRASIL, 2010, p. 8). ${ }^{23}$

Pode-se dizer, assim, que a escolha política adotada em 2012 decidiu por tratar como consolidadas as áreas rurais com intervenção antrópica anterior à 22 de julho de 2008 . Ao longo da pesquisa bibliográfica realizada, não foi encontrado fundamento que possibilitasse a concordância com mencionado marco, e inclusive aponta-se que seria razoável a adoção da data de promulgação do Decreto n. 3.179, de 22 de setembro de 1999 (este sim, foi o que pela primeira vez previu as infrações e sanções ambientais).

No entanto, há que se ponderar a existência do instrumento que permite aliviar, ainda que por outro meio, a evidente frustração da doutrina ambiental brasileira e demais representantes de órgãos e movimentos ambientalistas no país: o Programa de Regularização Ambiental (PRA), por ter como um de seus efeitos o uso regularizado das áreas rurais consolidadas, desde que o proprietário devidamente adira ao programa e assine o termo de compromisso (BRASIL, 2010; PAPP, 2012).

${ }^{23}$ Á época, ainda não havia se iniciado o trâmite legislativo do novo Código. 
Ademais, com o recente julgamento dessas questões pelo STF, não restam mais dúvidas a respeito da constitucionalidade dos artigos questionados nas ADI's propostas em face do Código Florestal, ou seja, de que a adoção da data de 22/07/2008 pela lei - e nisso ela se destaca para a anistia concedida aos crimes praticados até este marco - para aqueles que regularizem efetivamente suas propriedades por meio do PRA, não fere a Constituição.

\section{REFERÊNCIAS BIBLIOGRÁFICAS}

BRANDÃO, Júlio Cezar Lima. Novo Código Florestal Brasileiro: anotações à Lei 12.651/12. Curitiba: Juruá, 2012.

BRASIL. Câmara dos Deputados. Lei Florestal: Tabela Comparativa da lei 12.651/2012, da medida provisória 571/2012 e do texto do Senado Federal. Consultoria Legislativa (Cons. Ilídia da Ascenção Garrido Martins Juras e Roseli Senna Ganem), julho de 2012. 2012b. Disponível em: <http://www2.camara.leg.br/a-camara/documentos-e-pesquisa/estudos-enotas-tecnicas/areas-da-conle/tema14/2012_14640.pdf > . Acesso em: 03 dez. 2017.

BRASIL. Constituição da República Federativa do Brasil, de 05 de outubro de 1988. Disponível em: <http://www.planalto.gov.br/ccivil_03/Constituicao/Constituicao.htm>. Acesso em: 09 abr. 2018.

BRASIL. Decreto n' 3.179, de 21 de setembro de 1999. Dispõe sobre a especificação das sanções aplicáveis às condutas e atividades lesivas ao meio ambiente, e dá outras providências. Disponível em: < http://www.planalto.gov.br/ccivil_03/decreto/D3179.htm> Acesso em: 25 nov. 2017.

BRASIL. Decreto $\mathbf{n}^{\mathbf{0}} \mathbf{6 . 5 1 4}$, de 22 de julho de 2008. Dispõe sobre as infrações e sanções administrativas ao meio ambiente, estabelece o processo administrativo federal para apuração destas infrações, e dá outras providências. Disponível em: < http://www.planalto.gov.br/ccivil_03/_ato2007-2010/2008/decreto/d6514.htm>. Acesso em: 25 nov. 2017.

BRASIL. Lei n 4.771, de 15 de setembro de 1965. Institui o Novo Código Florestal. Disponível em: <http://www.planalto.gov.br/ccivil_03/leis/L4771.htm>. Acesso em: 27 nov. 2017.

BRASIL. Lei no 6.938, de 31 de agosto de 1981. Dispõe sobre a Política Nacional do Meio Ambiente, seus fins e mecanismos de formulação e aplicação, e dá outras providências. Disponível em: <http://www.planalto.gov.br/ccivil_03/leis/L6938.htm>. Acesso em: 14 nov. 2017.

BRASIL. Lei $\mathbf{n}^{\mathbf{0}} \mathbf{9 . 6 0 5}$, de 12 de fevereiro de 1998. Disponível em: <http://www.planalto.gov.br/ccivil_03/leis/L9605.htm>. Acesso em: 19 nov. 2017. 
BRASIL. Lei no 12.651, de 25 de maio de 2012. 2012a. Dispõe sobre a proteção da vegetação nativa; altera as Leis nos 6.938, de 31 de agosto de 1981, 9.393, de 19 de dezembro de 1996, e 11.428, de 22 de dezembro de 2006; revoga as Leis nos 4.771, de 15 de setembro de 1965, e 7.754, de 14 de abril de 1989, e a Medida Provisória no 2.166-67, de 24 de agosto de 2001; e dá outras providências. Disponível em: <http://www.planalto.gov.br/ccivil_03/_ato20112014/2012/lei/l12651.htm>. Acesso em: 27 nov. 2017.

BRASIL. Senado Federal. Agenda Legislativa para o Desenvolvimento Nacional. TAGLiAlEGNA, Gustavo Henrique Fideles. Reforma do Código Florestal: Busca do equilíbrio entre a agricultura sustentável e a preservação do meio ambiente. Disponível em: $<$ https://www12.senado.leg.br/publicacoes/estudos-legislativos/tipos-de-estudos/outraspublicacoes/agenda-legislativa/capitulo-3-reforma-do-codigo- florestal-busca-do-equilibrioentre-a-agricultura-sustentavel-e-a-preservacao-do-meio-ambiente> . Acesso em: 04 dez. 2017.

BRASIL. Supremo Tribunal Federal. Ação Direta de Inconstitucionalidade n. 4901. Rel. Min. Luiz Fux. Petição disponível em: $<$ http://terradedireitos.org.br/noticias/noticias/inconstitucionalidades-do-novo-codigoflorestal-serao-discutidas-em-audiencia-publica-no-stf/20406>. Acesso em: 04 dez. 2017.

BRASIL. Supremo Tribunal Federal. Ação Direta de Inconstitucionalidade n. 4937. Rel. Min. Luiz Fux. Petição disponível em: $<$ http://terradedireitos.org.br/noticias/noticias/inconstitucionalidades-do-novo-codigoflorestal-serao-discutidas-em-audiencia-publica-no-stf/20406>. Acesso em: 04 dez. 2017.

BRASIL. Supremo Tribunal Federal. ADI's 4901, 4902, 4903 e 4937: acompanhamento processual. 2012c. Disponível em: <http://portal.stf.jus.br/processos/detalhe.asp?incidente=4355097>. Acesso em: 09 abr. 2018.

BRASIL. Supremo Tribunal Federal. Notícias STF: Decano do STF profere o último voto em ações que discutem o novo Código Florestal, de 28 de fev. de 2018. Disponível em: <http://www.stf.jus.br/portal/cms/verNoticiaDetalhe.asp?idConteudo=370922>. Acesso em: 09 abr. 2018.

CONFEDERAÇÃO DA AGRICULTURA E PECUÁRIA DO BRASIL (CNA). Produzir e preservar: por que precisamos de um novo código florestal?. Brasília: CNA, 2011.

D'AGOSTINO, Rosanne. STF decide manter anistia a desmatadores concedida pelo Código Florestal. G1: Política, TV Globo. Disponível em: <https://g1.globo.com/politica/noticia/stf-decidemanter-anistia-do-codigo-florestal.ghtml> . Acesso em: 09 abr. 2018.

FIORILlO, Celso Antonio Pacheco. Curso de Direito Ambiental Brasileiro. $11^{\mathrm{a}}$ ed. rev., atual. e ampl. São Paulo: Saraiva, 2010. 
LEHFELD, Lucas de Souza; CARVALHO, Nathan Castelo Branco de; BALBIM, Leonardo Isper Nassif. Código Florestal comentado e anotado (artigo por artigo). São Paulo: Método, 2013.

LEUZINGER, Márcia Dieguez; CUREAU, Sandra. Direito Ambiental. Rio de Janeiro: Elsevier, 2008.

MACHADO, Paulo Affonso Leme. Direito Ambiental Brasileiro. 18 a ed., revista, atualizada e ampliada. São Paulo: Malheiros, 2010.

MILARÉ, Édis; MACHADO, Paulo Affonso Leme (coords.). Novo Código Florestal: comentários à Lei 12.651, de 25 de maio de 2012 e à MedPrev 571, de 25 de maio de 2012. $1^{\text {a }}$ ed. São Paulo: Revista dos Tribunais, 2012.

NOBRE, Thiago Lacerda. Novo Código Florestal comentado. Curitiba: Juruá, 2014.

PADILHA, Norma Sueli. Fundamentos Constitucionais do direito ambiental brasileiro. Rio de Janeiro: Elsevier, 2010.

PAPP, Leonardo. A revisão do Código Florestal brasileiro (Lei Federal n ${ }^{\circ}$ 12.651/12): reflexões iniciais acerca das APPs nas margens de cursos d'água naturais em áreas rurais consolidadas. Interesse Público - IP, Belo Horizonte, ano 14, n. 73, p. 121-142, maio/jun. 2012.

PETERS, Edson Luiz; PANASOLO, Alessandro. Reserva Legal e Áreas de Preservação Permanente à luz da nova lei florestal 12651/12. Curitiba: Juruá, 2014.

PRIOSTE, Fernando G. Vieira; AVANCI, Juliana; PACHER, Larissa; VIEIRA, Judith. Mudanças na legislação ambiental e os reflexos na agricultura familiar camponesa e povos e comunidades tradicionais: subsídios técnicos e políticos para o debate. Curitiba: 2009. Terra de Direitos Organização de Direitos Humanos, p. 10. Disponível em: $<$ http://terradedireitos.org.br/wp-content/uploads/2010/06/An\%C3\%A1lise-Terra-de-DireitosC\%C3\%B3digo-Florestal.pdf >. Acesso em: 18 nov. 2017.

SOS FLORESTAS (ONG). Código Florestal: Entenda o que está em jogo com a reforma da nossa legislação ambiental. [s.n.], 2011, 19 pgs. Disponível em: <https://www.wwf.org.br/?27443/Codigo-Florestal-Entenda-o-que-esta-em-jogo-com-areforma-de-nossa-legislacao-ambiental>. Acesso em: 04 dez. 2017. 